\title{
Article
}

\author{
Doi 10.5943/sif/6/1/37
}

\section{Aquatic hyphomycetes in the lateritic cave streams of Southwestern India}

\section{Sharathchandra $K^{1}$ and Sridhar $K_{R}^{1,2}$}

${ }^{1}$ Department of Biosciences, Mangalore University, Mangalagangotri, Mangalore, Karnataka, India

${ }^{2}$ Centre for Environmental Studies, Yenepoya (deemed to be) University, Mangalore, Karnataka, India

Sharathchandra K, Sridhar KR 2021 - Aquatic hyphomycetes in the lateritic cave streams of Southwestern India. Studies in Fungi 6(1), 480-487, Doi 10.5943/sif/6/1/37

\begin{abstract}
For the first time, assemblage and diversity of aquatic hyphomycetes were investigated in four lateritic cave streams of the southwest coast of India. This study includes physicochemical features of cave habitats and stream waters. Species richness, diversity and equitability of aquatic hyphomycetes in foam, water, leaf litter and woody litter (bark and cambium) have been investigated. These cave streams yielded up to 21 species of aquatic hyphomycetes, which is comparable to the population in nearby streams. The leaf litter of cave streams consist of highest number of species, while it was the lowest in the foam samples (15 vs. 7 spp.). Cave stream water, bark and cambium consist of 14, 11 and 9 species, respectively. Simpson's and Shannon's diversities were the highest in water samples, while the Pielou's equitability was highest in foam samples. The species richness as well as the core-group (highly frequent) aquatic hyphomycetes are comparable with nearby streams. Actinospora megalospora, Anguillospora angulata, A. crassa, Condylospora spumigena, Ingoldiella fibulata and Trinacrium subtile were the new records to the coastal region of southwest India.
\end{abstract}

Keywords - Bark - cambium - diversity - foam - leaf litter - water - woody litter

\section{Introduction}

Although aquatic hyphomycetes have been adapted mainly to the lotic habitats, they are also known from other ecological niches (e.g. terrestrial litter, lentic habitats, tree canopies and caves) (Sridhar 2009, Chauvet et al. 2016, Kozlova \& Mazina 2020, Sharathchandra \& Sridhar 2020, Sridhar et al. 2020). The microclimatic conditions exist in caves will be favourable for growth and functions of several fungi (Kozlova \& Mazina 2020). Fungal diversity in cave streams is of special interest owing to their diversity, adaptation, mineralization of organic matter and energy flow. Usually, fungi will be transferred to the caves by various routes (e.g. infiltration of spores through soil strata, insects, birds, bat guano and surface transfer of plant detritus) (Novákova 2009, SouzaSilva et al. 2012, Vanderwolf et al. 2013, Ghate \& Sridhar 2015, Prous et al. 2015, Kozlova \& Mazina 2020). Novákova (2009) depicted that the fungal diversity in karst cave ecosystems rely on the abundance of substrates. Due to cool and dark conditions in lateritic cave streams, various insects, birds and bats will be attracted and their activity will enrich the fungal population in water. In addition, penetrated roots from the cave roof, growth of algae, lichens, mosses, bryophytes and ferns on the walls of caves also support diverse mycota. However, the extent and diversity of biota vary in the photic zones (entrance part with light penetration) and dysphotic zones (feeble or 
without light penetration). Thus, there may be a gradient of biota in different parts of the cave streams.

Although aquatic hyphomycetes in the coastal region of the southwest coast of India have been evaluated in streams, intermittent streams, estuary, canopy and terrestrial litters (Sridhar \& Kaveriappa 1988, Sridhar et al. 1992, Sridhar 2009, Sridhar et al. 2013, Ghate \& Sridhar 2015, Sridhar et al. 2020, Sridhar \& Sharthchandra 2020), no studies are available in the lateritic cave streams. In the coastal region of southern Karnataka and northern Kerala, indigenous water management will be carried out by construction of horizontal tunnels up to 30-40 $\mathrm{m}(\sim 1 \times 2-2.5$ $\mathrm{m})$ besides the lateritic hills, which results in extraction of groundwater by the gravitational pull. This traditional knowledge has history over a century and the water source although feeble, it will be a permanent source to use for drinking, domestic and irrigation purposes. Occurrence of specific tree species (e.g. Ficus virens, Macranga indica and Vateria indica) and termite mounds confirms the water source as well as direction of tunnel construction. Such ventures will be performed during the summer season and percolating water will be collected in a tank. Approximately there are about 5000 lateritic caves exists in Kerala and Karnataka. Due to paucity of information on cave streams, the present study focuses the assemblage and diversity of aquatic hyphomycetes in four lateritic caves of southwestern region. This study involves evaluation of water parameters, species richness and diversity of aquatic hyphomycetes in water, foam, leaf litter and woody litter.

\section{Materials \& methods}

\section{Study sites and environmental parameters}

Four cave streams selected were Kodandooru, Pilinguli, Nekkare and Nayarmoole located in the southwestern Karnataka (12 $41^{\prime}$ N, 753' E) (Fig. 1). Tree species like Ficus spp., Macranga indica and Vateria indica were common in the vicinity of cave streams. The study has been carried out during the post-monsoon season (November 2020). Humidity and air temperature (Mextech Digital Thermo Hygrometer M288CTHW, Mumbai, India) and water temperature (mercury thermometer) ( $\sim 2 \mathrm{~m}$ inside the cave) were assessed. The $\mathrm{pH}$, conductivity and total dissolved solids (TDS) of cave waters were assessed using a water analysis kit (Water Analyzer 371, Systronics India Ltd., Ahmedabad, Gujarat, India). The water samples of caves were fixed on the sampling sites to assess dissolved oxygen by Winkler's method in the laboratory (APHA 1998). Other parameters such as total alkalinity, total hardness, chloride, inorganic phosphate, sulfate, silicate and magnesium of water samples were assessed as per the standard protocols of APHA (1998). The total alkalinity was determined by titration using strong acid followed by methyl orange and phenolphthalein indicators; total hardness was evaluated by ethylene diamine tetra-acetic acid (EDTA) titration method using eriochrome black-T and murexide indicators; chloride content was assessed by argentometric method (APHA 1998). The inorganic phosphate was found out by stannous chloride method; nitrate content was evaluated by brucine sulfanilic acid method; silicate and sulphate contents were determined by molybdosilicate and by turbidimetric methods, respectively (APHA 1998).

\section{Sampling and processing}

Three replicate samples of foam, water, leaf litter and woody litter from each cave stream were collected about 1-2 m outflow region. Overall scheme of assessment of samples is given in Fig. 2. The foam and water samples were assessed by direct microscopic examination, while the leaf litter, bark and cambium were assessed by indirect examination using bubble chamber incubation. Foam samples were fixed on the sampling site in formalin-acetic-alcohol (FAA: Mixture of $50 \mathrm{ml} \mathrm{95 \%} \mathrm{ethanol}+10 \mathrm{ml}$ glacial acetic acid $+10 \mathrm{ml} \mathrm{37 \%}$ formaldehyde $+30 \mathrm{ml}$ distilled water). Water samples $(25 \mathrm{ml}$ each) were filtered on the sampling site through the Millipore filters ( $5 \mu \mathrm{m}$ diameter) and stained the filters by aniline blue in lactophenol and stored in sterile Petri plates in dark. Submerged decomposing leaf and woody litters were collected in sterile polythene bags and transferred to laboratory. The leaf samples were rinsed in distilled water, 4-5 
different leaves were packed and punched into $1.5 \mathrm{~cm}$ disks using a cork borer. Leaf discs (4-5) per discs were transferred into conical flasks $(250 \mathrm{ml})$ with sterile distilled water $(150 \mathrm{ml})$ and aerated up to $48 \mathrm{hr}$ with fine jet of air with Pasteur pipette using aquarium aerator (bubble chamber incubation). From the woody litter, bark and cambium were separated and cut into segments $(\sim 0.2 \times 0.5 \times 2 \mathrm{~cm})$. Bark and cambium pieces $(4-5)$ were separately transferred in to the conical flasks and incubated in bubble chambers similar to the leaf discs. The aerated water of leaf discs, bark and cambium were filtered through Millipore filters ( $5 \mu \mathrm{m}$ diameter) and stained with aniline blue in lactophenol and stored in sterile petri plates in dark. Facesoffungi numbers of the cultures were registered as mentioned in Jayasiri et al. (2015).
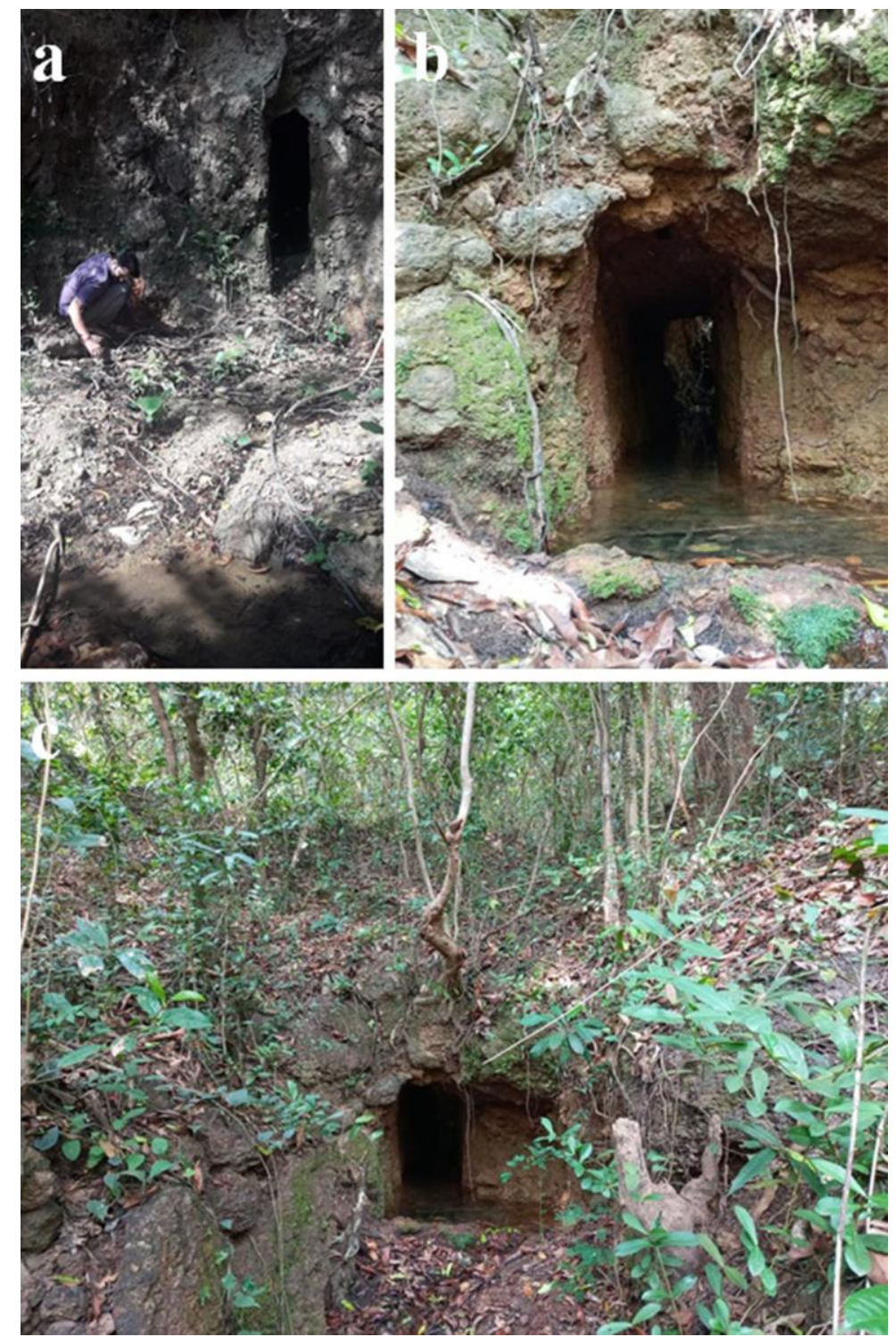

Fig. 1 - Sampling in Pilinguli cave stream (a), close up view (b) and overall view (c) of Nayarmoole cave stream.

Fixed foam samples were transferred drop by drop into the sterile slides and applied cover glass with a small quantity of aniline blue in lactophenol. Up to 300 conidia of aquatic hyphomycetes were scored per sample, different conidia were identified based on their morphology (Ingold 1975, Nawawi 1985, Marvanová 1997, Gulis et al. 2020) and the numbers of conidia of each species were enumerated. Stained filters of water samples $(25 \mathrm{ml}$ each) were cut into half, mounted on microscope slides with a few drops of lactic acid to score and identify the conidia, contribution of conidia of each species has been expressed in per cent. Stained filters of leaf discs, 
bark and cambium pieces were also assessed microscopically similar to water samples to identify and score the conidia. Aerated leaf discs, bark and cambium were dried at $80^{\circ} \mathrm{C}$ up to 24 hr to determine the dry mass. Conidial output per gram dry mass of substrate has been expressed in per cent contribution.

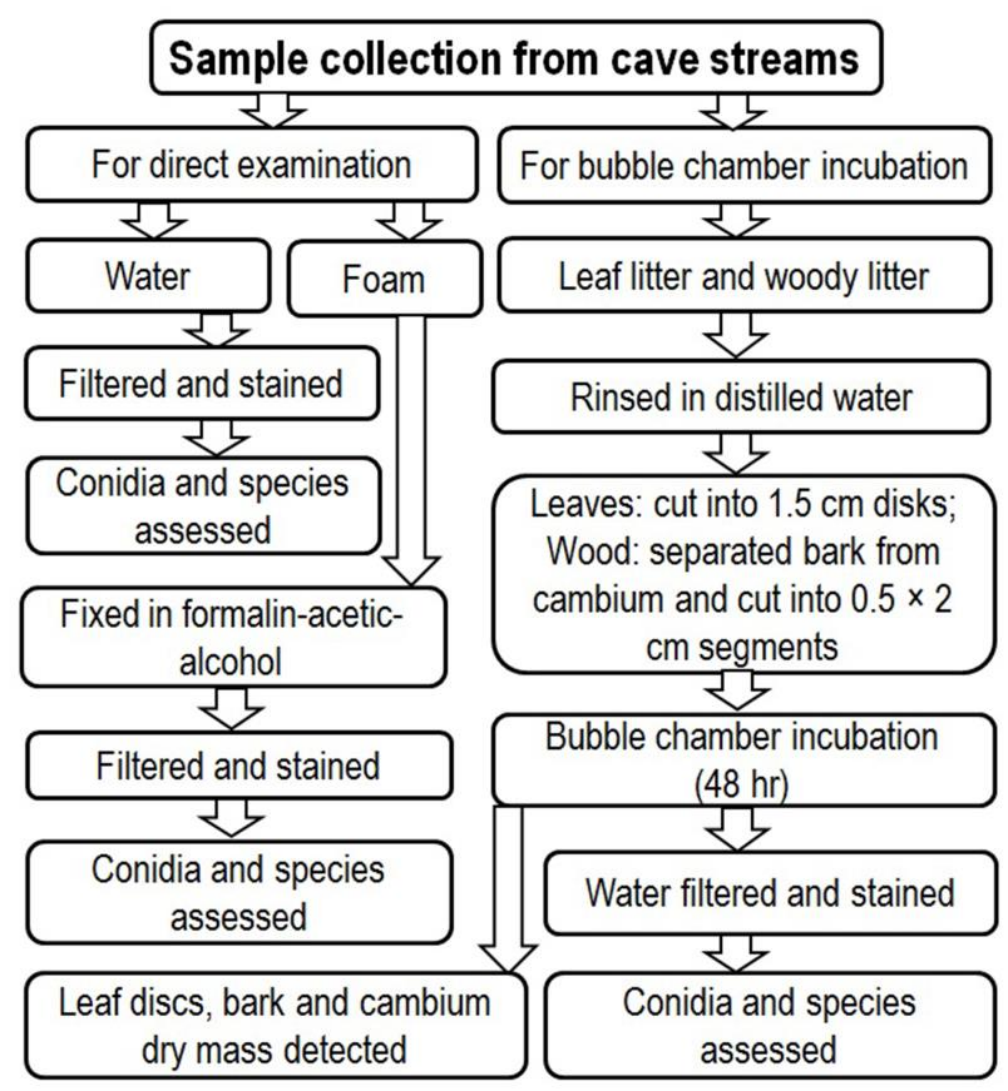

Fig. 2 - Scheme of direct and indirect assessment of cave stream samples for aquatic hyphomycetes.

\section{Data analysis}

Based on the mean conidia of each aquatic hyphomycete (among 300 conidia per foam sample), water (in $25 \mathrm{ml}$ sample), leaf litter, bark and cambium (per g dry mass) were compiled. This data was used to calculate the diversities (Simpson's and Shannon's diversity) (Magurran 1988) and Pielou's equitability (Pielou 1975).

\section{Results \& discussion}

Humidity in cave habitats ranged from $77.1-82.2 \%$, temperature of air was higher than water (30.1-32.2 vs. $21.3-25.2^{\circ} \mathrm{C}$ ) (Table 1 ). The $\mathrm{pH}$ of water samples was towards alkaline range (7.3-8.1) except for the cave Nekkare (6.9). The mean values of $\mathrm{pH}$, conductivity, total alkalinity, total hardness, chloride and magnesium contents of water samples fall within the range stipulated by the WHO (2004) standards for potability. However, the phosphate content exceeded the WHO (2004) standard (4.6 vs. $0.1 \mathrm{mg} / \mathrm{l}$ ). On comparison of cave stream water qualities with the ground water (bore well water) in a nearby region $(\sim 22 \mathrm{~km})$, water temperature, conductivity, total hardness, TDS, chloride and magnesium contents were lower, while the $\mathrm{pH}$ and phosphate content were higher (Bhagya \& Sridhar, unpublished observation).

\section{Aquatic hyphomycetes}

A total of 21 species of aquatic hyphomycetes was found in cave streams (Fig. 3). The number of species were highest in leaf litter (15 spp.) followed by water (14 spp.), bark (11 spp.), 
cambium (9 spp.) and foam (7 spp.) samples (Table 2). Water samples showed the highest Simpson's and Shannon's diversities, while they were least in leaf litter and foam samples, respectively (Table 3 ). The species richness was highest (9 spp.) in water samples of the cave Nayarmoole followed by water in Pilinguli and leaf litter in Kodandooru (8 spp.) (Fig. 4). Water and leaf litter of Nekkare cave and leaf litter of Nayarmoole cave possess $7 \mathrm{spp}$. The number of species of aquatic hyphomycetes in cave streams is comparable with Konaje stream located about $20 \mathrm{~km}$ from the cave streams (Sridhar \& Kaveriappa 1984, 1989a, b, Sridhar et al. 2013). Similarly, the top three species (Anguillospora longissima, Flagellospora curvula and Lunulospora curvula) matches with the earlier studies in nearby streams (Sridhar et al. 2013, Ghate \& Sridhar 2015). Besides these species, Anguillospora crassa also constitutes a core-group species in the cave streams. In addition, Actinospora megalospora, Anguillospora crassa, Anguillospora angulata, Condylospora spumigena, Ingoldiella fibulata and Trinacrium subtile were the additional species not found in earlier studies (Sridhar \& Kaveriappa 1984, Sridhar et al. 2013, Ghate \& Sridhar 2015).

Table 1 Physicochemical features of four lateritic cave streams (mean, $\mathrm{n}=3$ )

\begin{tabular}{|c|c|c|c|c|c|}
\hline & \multicolumn{4}{|l|}{ Cave } & \multirow{2}{*}{$\begin{array}{l}\text { Overall } \\
\text { mean } \pm \text { SD }\end{array}$} \\
\hline & Kodandooru & Pilinguli & Nekkare & Nayarmoole & \\
\hline Humidity (\%) & 78.1 & 80.8 & 77.1 & 82.2 & $79.6 \pm 2.4$ \\
\hline Air temperature & 31.1 & 32.2 & 30.1 & 31.7 & \\
\hline $\begin{array}{l}\left({ }^{\circ} \mathrm{C}\right) \\
\text { Water temperature }\end{array}$ & 23.2 & 21.3 & 24.1 & 25.2 & $31.3 \pm 0.9$ \\
\hline$\left({ }^{\circ} \mathrm{C}\right)$ & & & & & $23.5 \pm 1.7$ \\
\hline $\mathrm{pH}$ & 7.3 & 7.7 & 6.9 & 8.1 & $7.5 \pm 0.5$ \\
\hline $\begin{array}{l}\text { Conductivity } \\
(\mu \mathrm{S} / \mathrm{cm})\end{array}$ & 51.0 & 44.0 & 69.6 & 55.6 & $55.1 \pm 10.8$ \\
\hline $\begin{array}{l}\text { Dissolved oxygen } \\
(\mathrm{mg} / \mathrm{l})\end{array}$ & 8.6 & 8.2 & 8.0 & 8.9 & $8.4 \pm 0.4$ \\
\hline $\begin{array}{l}\text { Total alkalinity } \\
(\mathrm{mg} / \mathrm{l})\end{array}$ & 30.5 & 39.6 & 26.9 & 42.9 & $35.0 \pm 7.5$ \\
\hline $\begin{array}{l}\text { Total hardness (as } \\
\mathrm{CaCO}_{3} \text { ) }\end{array}$ & 16.6 & 22.4 & 27.2 & 24.2 & $22.6 \pm 4.5$ \\
\hline $\begin{array}{l}\text { Total dissolved } \\
\text { solids (mg/l) }\end{array}$ & 25.2 & 24.8 & 39.2 & 42.9 & $33.0 \pm 9.4$ \\
\hline Chloride (mg/l) & 4.4 & 4.3 & 6.2 & 7.3 & $5.6 \pm 1.5$ \\
\hline Sulphate (mg/l) & 1.8 & 2.4 & 2.7 & 1.9 & $2.2 \pm 0.4$ \\
\hline Phosphate (mg/l) & 6.2 & 4.9 & 2.6 & 4.5 & $4.6 \pm 1.5$ \\
\hline Silicate $(\mathrm{mg} / \mathrm{l})$ & 23.5 & 18.1 & 26.7 & 22.5 & $22.7 \pm 3.6$ \\
\hline Magnesium (mg/l) & 3.2 & 4.5 & 6.3 & 4.3 & $4.6 \pm 1.3$ \\
\hline
\end{tabular}

Table 2 Per cent contribution of conidia of aquatic hyphomycetes in lateritic cave streams $(n=4$, mean) (*, among 300 conidia in foam; **, in $25 \mathrm{ml}$ water; ***, in g dry mass of leaf, bark and cambium)

\begin{tabular}{|c|c|c|c|c|c|}
\hline & \multirow{2}{*}{\multicolumn{2}{|c|}{ Direct observation }} & \multicolumn{3}{|c|}{ Bubble chamber incubation } \\
\hline & & & \multirow{2}{*}{ Leaf litter } & \multicolumn{2}{|c|}{ Woody litter } \\
\hline & Foam & Water & & Bark & Cambium \\
\hline Species richness & 7 & 14 & 15 & 11 & 9 \\
\hline Simpson diversity & 0.809 & 0.835 & 0.796 & 0.812 & 0.828 \\
\hline Shannon diversity & 2.541 & 3.005 & 2.967 & 2.893 & 2.724 \\
\hline Pielou's equitability & 0.905 & 0.789 & 0.759 & 0.836 & 0.859 \\
\hline
\end{tabular}


Table 3 Species richness, diversity and equitability of aquatic hyphomycetes in lateritic cave streams

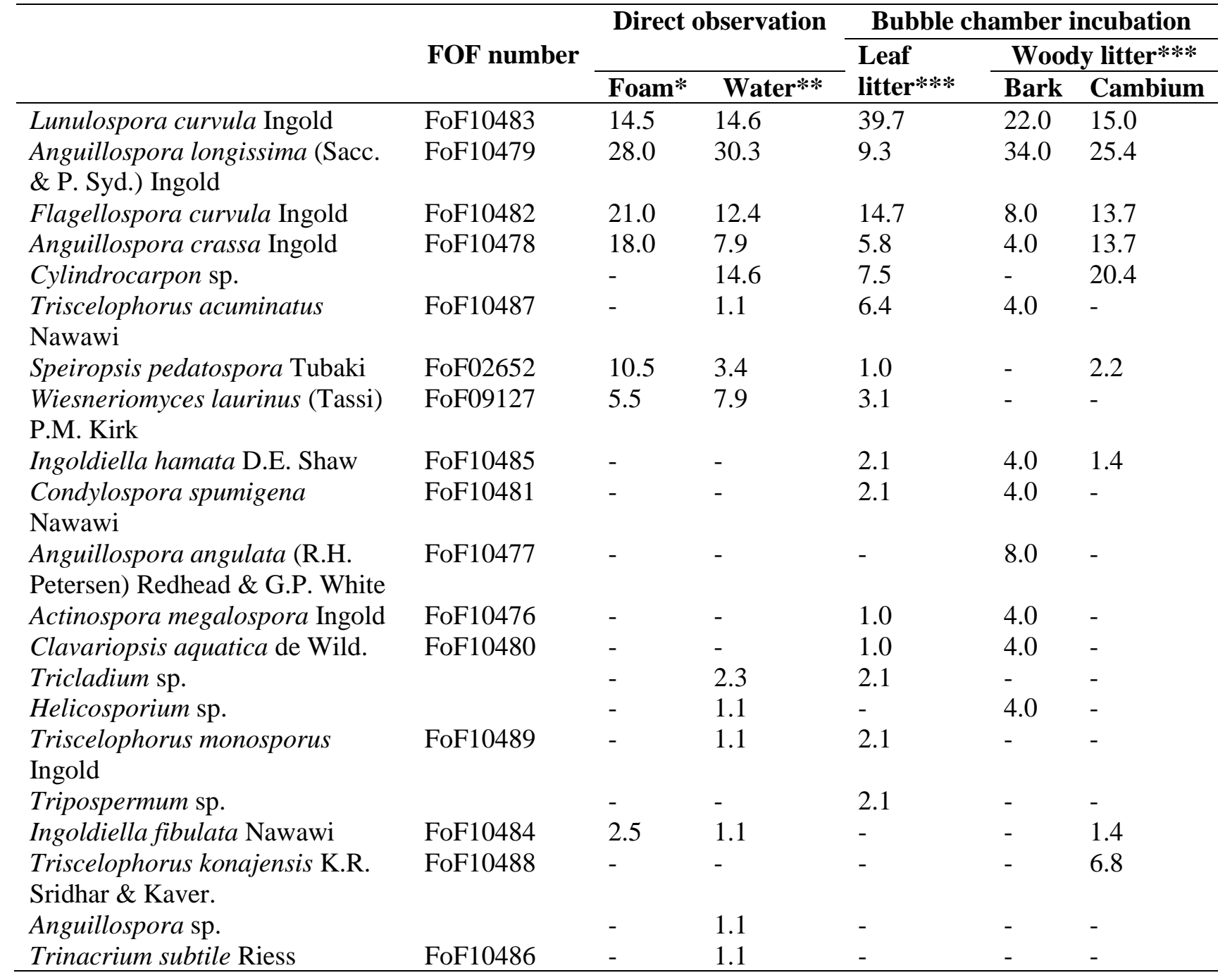

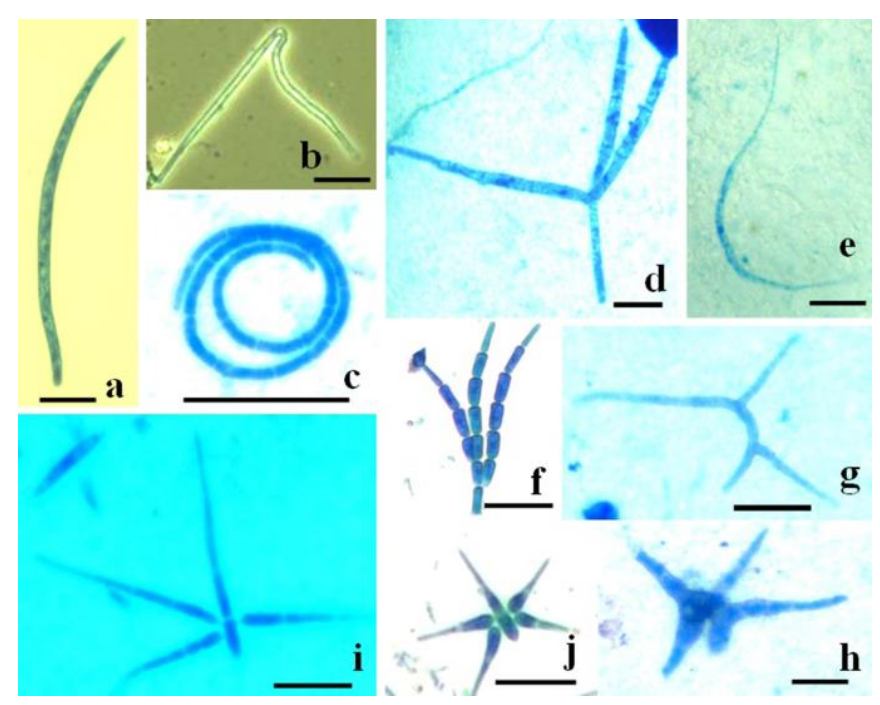

Fig. 3 - Conidia of selected aquatic hyphomycetes obtained from the lateritic cave stream samples. a Anguillospora crassa. b Condylospora spumigena. c Helicosporium sp. d Ingoldiella hamata. e Lunulospora curvula. f Speiropsis pedatospora. g Tricladium sp. h Tripospermum sp. i Triscelophorus acuminatus. $\mathrm{j}$ Triscelophorus konajensis. Scale bars $=20 \mu \mathrm{m}$. 


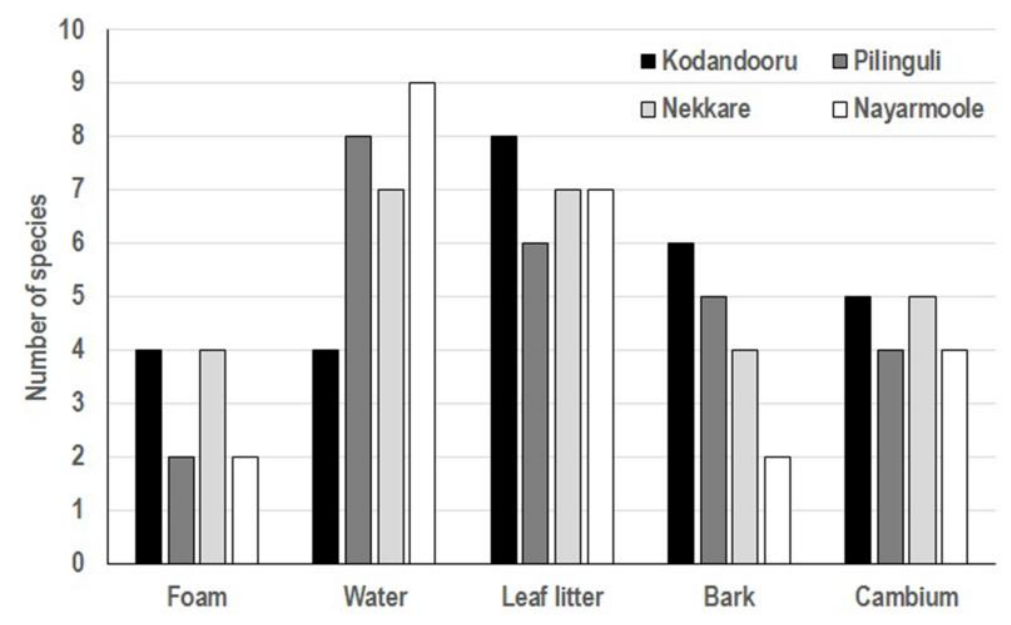

Fig. 4 - Species richness of aquatic hyphomycetes in different samples in lateritic cave streams.

\section{Conclusions}

From the four cave streams (Kodandooru, Pilinguli, Nekkare and Nayarmoole located in the southwestern India) foam, water, leaf litter and woody litter samples yielded up to 21 species of aquatic hyphomycetes, which is comparable to the population in nearby streams. The species richness was highest (9 spp.) in water samples of the cave stream Nayarmoole followed by water samples of Pilinguli and leaf litter samples of Kodandooru (8 spp.) cave streams. The highest richness of aquatic hyphomycetes was found in leaf litter (bubble chamber incubation) (15 spp.) followed water (direct examination) (14 spp.) and bark (bubble chamber incubation) (11 spp.). The frequent core-group fungi matches with other studies carried out in nearby streams. Simpson's and Shannon's diversities were higher in water samples than other samples. Six aquatic hyphomycetes (Actinospora megalospora, Anguillospora crassa, Anguillospora angulata, Condylospora spumigena, Ingoldiella fibulata and Trinacrium subtile) were the new records to the southwestern India. Cave stream water being used for drinking and domestic purposes, the water quality almost fulfils the WHO (2004) stipulated standards.

\section{Acknowledgements}

Authors are indebted to the Department of Biosciences, Mangalore University for the facilities to carry out this study. Authors are thankful to Dr. Thilini Chethana for providing the Faces of Fungi (FOF) numbers for the species.

\section{References}

APHA. 1998 - Standard Methods for the Examination of Water and Wastewater. 20th Edition. American Public Health Association, American Water Works Association and Water Environmental Federation, Washington DC, USA.

Bhagya BS, Sridhar KR. 2021 - Assessment of groundwater quality for potability in southwest Karnataka State, India (unpublished observation).

Chauvet E, Cornut J, Sridhar KR, Sélosse M-A, Bärlocher F. 2016 - Beyond the water column: Aquatic hyphomycetes outside their preferred habitats. Fungal Ecology 19, 112-127.

Ghate SD, Sridhar KR. 2015 - Diversity of aquatic hyphomycetes in sediments of temporary streamlets of Southwest India. Fungal Ecology 14, 53-61.

Gulis V, Marvanová L, Descals E. 2020 - An illustrated key to the common temperate species of aquatic hyphomycetes. In: Methods to Study Litter Decomposition: A Practical Guide. Bärlocher F, Gessner MO, Graça MAS (eds), Springer Nature Switzerland pte Ltd., pp 223-240. 
Ingold CT. 1975 - An Illustrated Guide to Aquatic and Water-Borne Hyphomycetes (Fungi Imperfecti) with Notes on their Biology. Freshwater Biological Association Scientific Publication \# 30. Ambleside, UK, p 96.

Jayasiri SC, Hyde KD, Ariyawansa HA, Bhat J et al. 2015 - The Faces of Fungi database: fungal names linked with morphology, phylogeny and human impacts. Fungal Diversity 74(1), 3-18. Doi 10.1007/s13225-015-0351-8

Kozlova EV, Mazina SW. 2020 - Biodiversity of fungi in the photic and aphotic zones of Montenegro caves. Aerobiologia 36, 589-604.

Marvanová L. 1997 - Freshwater hyphomycetes: A survey with remarks on tropical taxa, In: Tropical Mycology. Janardhanan KK, Rajendran C, Natarajan K, Hawksworth DL (eds). Science Publishers, Enfield, USA, pp 169-226.

Magurran AE. 1988 - Ecological Diversity and its Measurement. Princeton University Press, Princeton, USA.

Nawawi A. 1985 - Aquatic hyphomycetes and other waterborne fungi from Malaysia. Malaysian Nature Journal 39, 75-134.

Novákova A. 2009 - Microscopic fungi isolated from the Domica Cave system (Slovak Karst National Park, Slovakia). A review. International Journal of Speleology 38, 71-82.

Pielou FD. 1975 - Ecological Diversity. Wiley InterScience, New York.

Prous X, Ferreira, RL, Jacobi CM. 2015 - The entrance as a complex ecotone in a Neotropical cave. International Journal of Speleology 44, 177-189.

Sharathchandra K, Sridhar KR. 2020 - Ingoldian fungi in terrestrial damp woody litter of five tree species. MycoAsia 2020/07, 1-12.

Sridhar KR. 2009 - Fungi in the tree canopy: An appraisal. In: Rai M, Bridge P (Ed.). Applied Mycology. CAB International, UK, 73-91.

Sridhar KR, Chandrashekar KR, Kaveriappa KM. 1992 - Research on the Indian subcontinent. In: Bärlocher F (Ed.). The Ecology of Aquatic Hyphomycetes (Ed.). Springer-Verlag, Heidelberg, 182-211.

Sridhar KR, Karamchand KS, Seena S. 2013 - Fungal assemblage and leaf litter decomposition in riparian tree holes and in a coastal stream of the south-west India. Mycology 4, 118-124.

Sridhar KR, Kaveriappa KM. 1984 - Seasonal occurrence of water-borne fungi in Konaje stream (Mangalore), India. Hydrobiologia 119, 101-105.

Sridhar KR, Kaveriappa KM. 1988 - Occurrence and survival of aquatic hyphomycetes in brackish and seawater. Archiv für Hydrobiologie 113, 153-160.

Sridhar KR, Kaveriappa KM. 1989a - Observations on aquatic hyphomycetes of the Western Ghat streams, India. Nova Hedwigia 49, 455-467.

Sridhar KR, Kaveriappa KM. 1989b - Colonization of leaves by water-borne hyphomycetes in a tropical stream. Mycological Research 92, 392-396.

Sridhar KR, Nagesh H, Sharathchandra K. 2020 - Assemblage and diversity of asexual fungi in 10 terrestrial damp leaf litters: Comparison of two incubation techniques. Asian Journal of Mycology 3, 362-375.

Souza-Silva M, Bernardi LFO, Martins RP, Ferreira RL. 2012 - Transport and consumption of organic detritus in a neotropical limestone cave. Acta Carsologica, 41, 139-150.

Vanderwolf K, Malloch D, McAlpine DF, Forbes GJ. 2013 - A world review on fungi, yeasts, and slime molds in caves. International Journal of Speleology 42, 77-96.

WHO. 2004 - Guidelines for Drinking Water Quality: Recommendations. Third Edition, Volume 1, World Health Organization, Geneva, Rome. 